\title{
On the Seedling Structure of Gymnosperms. III.
}

\author{
BY \\ T. G. HILL, F.L.S., \\ University of London; University and Goldsmiths' Colleges; \\ AND \\ E. DE FRAINE, F.L.S. \\ University of London; Goldsmiths' College.
}

With Plate $\mathbf{X X X}$, and four Figures in the Text.

GINKGOACEAE.

Ginkgo biloba.

THE appearance of the seedling of this plant, and the germination 1 of the seed, have already been described and figured by Sprecher, ${ }^{2}$ and are sufficiently well known to render an extended description unnecessary. Figs. I-3, P1. XXX will suffice to recall its more obvious features : the cotyledons usually are two in number but three sometimes occur (Fig. 3, Pl. XXX), a fact already recorded by Lyon ${ }^{1}$ and Sprecher. ${ }^{2}$

The seed-leaves are frequently unequal in length; they exhibit a more or less well-marked lobing, and throughout their existence, remain embedded within the seed where they are closely adpressed by their ventral surfaces. These facts have already been remarked upon by Strasburger, ${ }^{3}$ Worsdell, ${ }^{4}$ and Seward and Gowan. ${ }^{5} \quad$ According to Lyon ${ }^{6}$ the seed-leaves are normally equal and entire. Towards the basal region the cotyledons separate in the manner indicated in Fig. 2, Pl. XXX. Although the details of the histology of the seed-leaves have been investigated by other authors, more especially by Sprecher, ${ }^{7}$ it will not be out of place to draw

${ }^{1}$ Lyon: Embryogeny of Ginkgo (Minnesota Bot. Studies, 1904).

${ }^{2}$ Sprecher: Le Ginkgo biloba (Genève, 1907).

3 Strasburger: Die Coniferen und die Gnetaceen (Jena, I872).

${ }^{4}$ Worsdell : On Transfusion Tissue : its Origin and Function in the Leaves of Gymnospermous Plants. (Trans. Linn. Soc. Lond.; Bot., 2nd Ser., v.)

5 Seward and Gowan: The Maidenhair Tree (Ginkgo biloba). (Ann. Bot. xiv, I900.)

6 loc. cit.

7 loc. cit.

[Annals of Botany, Vol. XXIII. No. XCI. July, 1909.] 
attention to some of the more salient facts. Their structure is simple; the mesophyll is homogeneous with its parenchymatous elements densely crowded with starch grains; also stomata occur, a feature which has been fully considered by Wigglesworth ${ }^{1}$ and Sprecher. ${ }^{2}$

Resin-ducts are present, they appear first at the corners of the cotyledons, but at lower levels several may be present (Diagram I, Figs. 2 and 6); also secretory cells are abundant.

The chief feature of interest in the structure of the vascular bundles is their mesarch structure, a fact which has been recorded by Worsdell ${ }^{3}$ and other observers. On the outer side of the soft bast is a band of fibrous elements precisely similar to the same tissue alluded to in the case of many of the plants already considered ${ }^{4}$ (Diagram I, Figs. 3 and 5 ).

\section{Transition.}

Each seed-leaf has four vascular strands at the apex arranged in two pairs (Diagram I, Fig. I). In one plant examined a cotyledon had but three strands at its distal end; but, at a lower level, an extra bundle developed next to the odd one, so that equality was constituted. Tracing these strands downwards, the individuals of each pair approach each other, and a union is brought about by the fusion of the fibrous elements on the outer side of the soft bast (Diagram I, Fig. 2). This condition is maintained for some distance: the bundles, as viewed in transverse section, appear semi-circular in outline with the two xylem masses facing each other in the manner indicated in Diagram I, Fig. 3. At the same time the wood has become more compact, and new xylem elements may appear between the centripetal tracheides; this before the actual fusion of the two groups of vascular tissue has taken place. At a lower level the union is consummated so that each cotyledon now has two mesarch bundles with the vascular arrangement indicated in Diagram I, Figs. 4 and 5 .

This condition persists for some distance downwards: then, as the strands are traced towards the cotyledonary node, they are seen gradually to approach one another and ultimately to fuse, first by the fibrous elements (Diagram I, Fig. 6), and then by the soft bast. The metaxylems are connected together by the protoxylem elements which are tangentially extended; they-the metaxylems - may or may not fuse (Diagram 1, Figs. 7 and 8 ) and in this state the bundles enter the hypocotyledonary axis.

It may be remarked here that some earlier authors (Worsdell, ${ }^{5}$ Seward and Gowan, ${ }^{6}$ and Sprecher ${ }^{7}$ ) are all agreed upon the presence of two bundles throughout the main length of each cotyledon and the occurrence of one trace at the base of the seed-leaf, but they have not remarked upon

1 Wigglesworth: The Cotyledons of Ginkgo biloba and Cycas revoluta (Ann. Bot., xvii, I903).

${ }^{2}$ loc. cit. 3 loc, cit.

5 loc. cit.

6 loc. cit.

1 Parts I and II, Ann. Bot., I908, I909.

7 loc. cit. 


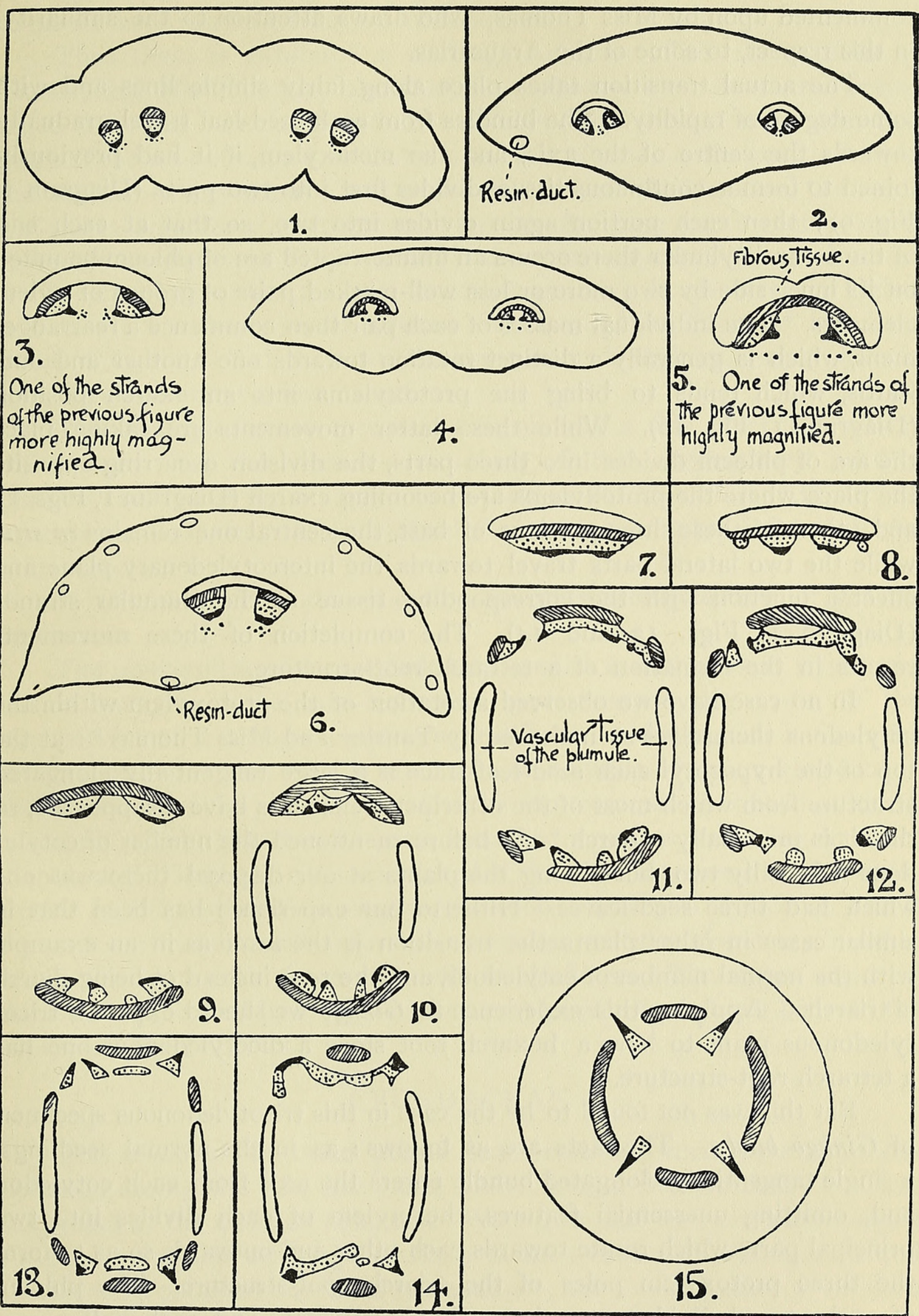

Diagram I. Ginkgo biloba.-In this, and in the following text-figures, the protoxylem is indicated by black areas, the metaxylem by dots, and the phloem by shading. 
the presence of four strands at the apex. This feature has, however, been commented upon by Miss Thomas, ${ }^{1}$ who draws attention to the similarity, in this respect, to some of the Araucarias.

The actual transition takes place along fairly simple lines and with some degree of rapidity. The bundles from each seed-leaf travel gradually towards the centre of the axis, and the metaxylem, if it had previously joined to form a continuous tissue, divides first into two parts (Diagram I, Fig. 9); then each portion again divides into two, so that at each end of the central cylinder there occurs an uninterrupted arc of phloem bounded on its inner side by two more or less well-marked pairs of groups of xylem elements. The individual masses of each pair then commence a rearrangement, which is generally a distinct rotation towards one another and outwards, which tends to bring the protoxylems into an exarch position (Diagram I, Fig. IO). While these latter movements are taking place the arc of phloem divides into three parts, the division occurring opposite the place where the protoxylems are becoming exarch (Diagram I, Figs. I I and I2). Of these three portions of bast, the central one remains in situ, while the two lateral parts travel towards the intercotyledonary plane and effect a junction with the corresponding tissue of the plumular strands (Diagram I, Figs. I3 and I4). The completion of these movements results in the formation of a tetrarch root-structure.

In no case have we observed a rotation of the protoxylem within the cotyledons themselves as indicated by Tansley and Miss Thomas ${ }^{2}$ : at the top of the hypocotyl each seed-leaf-trace is a large tangentially elongated structure from which most of the centripetal elements have disappeared, so that it is practically endarch. As before mentioned the number of cotyledons is usually two, but among the plants at our disposal there was one which had three seed-leaves. Hitherto our experience has been that in similar cases in other plants, the transition is the same as in an example with the normal number of cotyledons, and the root instead of being diarch is triarch. Applying this experience to Ginkgo we should expect a tricotyledonous plant to have a hexarch root since a dicotyledonous one has a tetrarch root-structure.

But this was not found to be the case in this tricotyledonous specimen of Ginkgo biloba. The facts are as follows: as in the normal seedlings, a single tangentially elongated bundle enters the axis from each cotyledon and, omitting unessential features, the xylem of each divides into two principal parts which rotate towards each other and outwards so as to form the three protoxylem poles of the triarch root-structure. The phloem of each strand divides opposite each protoxylem, and each half passes vi, 1907).

1 Thomas: a Theory of the Double Leaf-Trace founded on Seedling-Structure (New Phytologist,

2 Tansley and Thomas. Discussion on Seedling-Structure. Brit. Assoc. York, Sect. K. I906. 
to one side and fuses with the adjacent bast of the epicotyledonary structures, so there results a triarch root-structure.

Thus there is exhibited a striking variation. The observations of Tansley and Miss Thomas, ${ }^{1}$ and also our own, show that the normal occurrence is for the vascular tissue derived from each cotyledon to form two poles of the root-structure, so that the number of poles in the root is double the number of cotyledons ; but, in the case under consideration, the seedleaf-traces organize a root-structure having the same number of poles as there are cotyledons. This variation does not appear to be uncommon, for Sprecher ${ }^{2}$ describes the root-structure as being hexarch in the higher regions which at lower levels becomes diarch, and Miss Thomas, ${ }^{3}$ in a later publication, states that the tetrarch arrangement is fugitive, giving place to a diarch structure at a lower level.

This tricotyledonous specimen also showed a few other, but minor, differences; thus the mesarch structure of the cotyledonary bundles persisted relatively_for a longer time than in the case of dicotyledonous examples; also, one seed-leaf joined the axis at a higher level than the other two.

It remains to draw attention to a few outstanding features of general occurrence.

The protoxylem of the cotyledonary bundles is well marked, it becomes less, in amount as the seed-leaf-traces pass towards the centre of the hypocotyl, and it becomes increasingly difficult to distinguish it from the metaxylem. Further, there is often seen an addition of xylem elements on the outer side of the protoxylem after the root-structure has been attained, a feature which has already been remarked upon as occurring in other plants, e.g. Funiperus virginianus and Libocedrus decurrens. ${ }^{4}$ An endodermis is differentiated as soon as the root-structure is arrived at, and it occurs some distance out from the outermost vascular elements; in other words the 'pericycle' is several cells in thickness. The upper region of the root is protected by a well-marked exodermis situated just beneath the superficial layer of cells.

\section{CYCADACEAE.}

The seedlings of these plants have received much attention from botanists during the last few years, and reference will be made to these researches as the occasion demands. We regret that we have been enabled to examine so few seedlings of these plants; seeds of other genera and species were obtained but failed to germinate, and in other cases, even when germination was successful, many damped off before a stage suitable for our investigation was reached.

$$
\begin{array}{lll}
1 \text { loc. cit. } & 2 \text { loc. cit. } \\
3 \text { loc. cit. } & 4 \text { Part I, Ann. Bot. I908. }
\end{array}
$$


Finally, it may be remarked that as this particular series of papers is already somewhat detailed and lengthy, it has been considered desirable to make little or no mention of histological features of the Cycadaceae, more especially of the vascular bundles, here. They may, if necessary, form the subject of a separate communication.

\section{MACROZAMIA.}

Macrozamia spiralis.

The form of the seedling closely resembles that of Ginkgo and is illustrated in Fig. 4, Pl. XXX. There are two hypogeal cotyledons which, throughout their existence, remain embedded in the endosperm of the seed ; they are of unequal size, and the larger one is also often slightly longer, its tip sometimes being folded over the free end of the smaller.

The seed-leaves are very closely adpressed by their ventral surfaces; at the apex, and a little below, the epidermis of each member forms a line of demarcation, but at a slightly lower level the fusion appears to be quite complete, the ventral epidermis can no longer be distinguished, and a transverse section has all the appearances of a section of a stem.

At a still lower level the boundary line again appears and, towards their bases, the seed-leaves partly separate to form a cotyledonary tube which encloses the plumule.

As regards structure little need be said. Stomata, sunken below the general level of the epidermis, have been observed, and they are restricted, as far as has been seen, to the dorsal surface where the cuticle is fairly well pronounced and thicker than on the ventral surface. The internal structure resembles very closely that of Ginkgo. The compact mesophyll is homogeneous, and its parenchymatous cells are densely packed with starch grains. Secretory cells are abundant, and also mucilage canals of a large size; the number of these latter varies, about five in each seed-leaf are present.

The vascular bundles are not particularly large, and they vary in number in each seed-leaf; the smaller cotyledon generally has one less than the larger, which usually has five; six, however, were observed in one case. The vascular strands are very markedly mesarch in structure ; most, in some cases practically all, of the metaxylem is centripetal.

At the extreme apex of each cotyledon there is often but one vascular strand consisting of a broad tangentially elongated mass of tracheides but no phloem ; this strand, as it is traced downwards towards the base, quickly divides up into four, five, or six bundles, according to the size of the cotyledon, and phloem is differentiated. The number of bundles thus produced generally remains constant, so that five strands enter the hypocotyledonary axis from one seed-leaf and four from the other. But in one case it was observed that the larger cotyledon had six strands and the 
smaller five,'some of which fused together so that four entered the axis from each seed-leaf.

These observations are in agreement with those of Worsdell, ${ }^{1}$ who has briefly investigated the seedling of this plant and draws attention to the similarity of $M$. spiralis and Cycas in the structure of the cotyledons.

\section{Transition.}

Taking the commoner occurrence, as regards the number of cotyledonary traces, nine vascular bundles enter the hypocotyledonary axis and travel towards the centre with some degree of rapidity, so that, in transverse sections, the traces are always very oblique, which renders it almost impossible to distinguish the protoxylem elements from the metaxylem, for which reason the protoxylem has not been indicated in all the figures of the second and succeeding Diagrams. During the passage various fusions take place between adjacent bundles; thus, to take a concrete case which is illustrated in Diagram 2, $i$ joins up with $a$ (Diagram 2, Fig. 1) $c$ and $d$, as they pass inwards, approach each other and fuse (Diagram 2, Figs. 2 and 3 ) ; and likewise the bundles $f$ and $g$. At a slightly lower level $b$ joins with the compound bundle $c d$ and, similarly, $h$ fuses with $f g$. So far $e$ has remained isolated, but it very soon effects a junction with $f g h$, by which time the xylem-masses of the cotyledonary strands have fused with what wood is present belonging to the plumular traces. There is thus formed a very irregular core of xylem, which, sometimes, is roughly three-rayed, in the centre of the axis. The phloem-masses also fuse so that the vascular tissue derived from the cotyledons and from the plumule forms a single concentric cylinder (Diagram 2, Fig. 6). This condition obtains only through a very short length of the axis; the phloem separates into two masses situated in the intercotyledonary plane and, concurrently, the xylem elements, which by now are rather less numerous than before, become organized to form a well-marked diarch plate situated in the cotyledonary plane.

In no case has a transient tetrarch root-structure been observed, and, so far as has been seen, it is generally diarch, an observation which is in agreement with Worsdell's ${ }^{2}$ experience. During these later changes, as has already been remarked, it is impossible to trace the protoxylem or to distinguish it from the metaxylem owing to the numerous and complicated anastomoses. It is therefore impossible to say whether or not all the cotyledon-traces are equally important in the formation of the resulting root-structure. It is obvious, from the strongly mesarch nature of the cotyledonary bundles, that the rotation of the protoxylem is of very little importance for the amount of centrifugal wood is so small that only a slight

1 Worsdell : The Comparative Anatomy of certain Genera of the Cycadaceae (Journ. Linn. Soc. Lond., Bot., xxxiii).

2 loc. cit. 


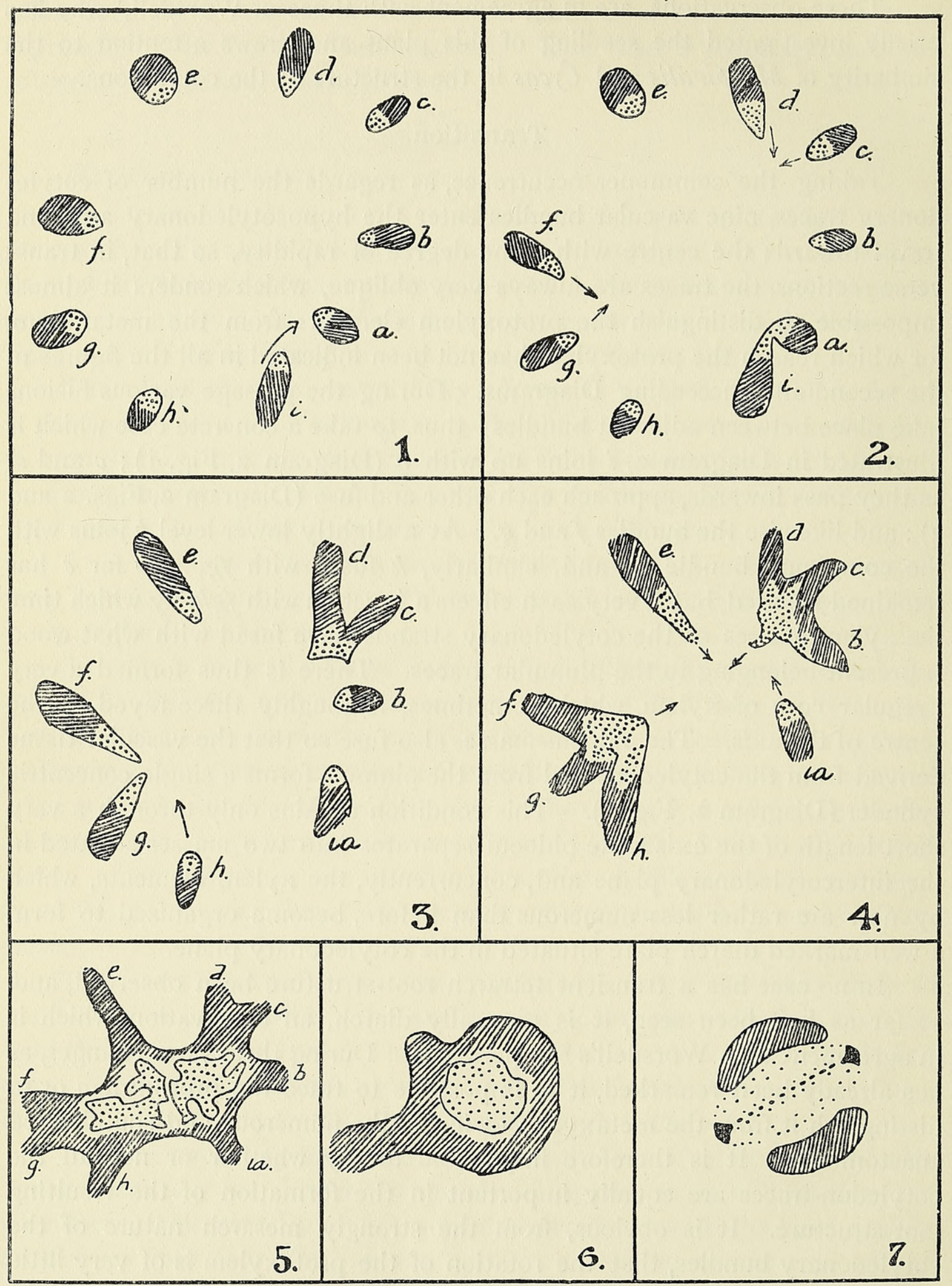

Diagram 2. Macrozamia spiralis. 
amount of rearrangement is necessary in order to bring the protoxylem into its exarch position.

As regards minor features, an endodermis does not appear until a much lower level has been reached, but a well-marked exodermis, two or three layers of cells in thickness, is conspicuous.

The metaxylem situated between the phloem-masses of the root soon disappears and, at the same time, the protoxylems become tangentially expanded (Diagram 2, Fig. 7). It is almost unnecessary to remark that the smaller details of the transition region are not precisely the same in the different individuals examined, but the above account is typical of the species as regards essential features, so far as can be judged from the material at our disposal.

Attention may be drawn to another seedling of this species which was the only one that germinated out of a number of seeds sent to us as $M$. corallipes; its external morphology is precisely similar to that of the other seedlings of $M$. spiralis, and so also is the structure of the cotyledons, with the exception that the secretory cells are less numerous and the mucilageducts fewer and not so well marked.

With regard to the transition, the number of bundles towards the apex of the seed-leaves is more numerous than in the other examples, there being ten in the larger cotyledon and eight in the smaller. These strands, as they are followed downwards towards the node, fuse together to form four, which are arranged in two pairs, in each seed-leaf. The units of each pair of strands fuse together, either at the base of the cotyledon or in the outer regions of the uppermost part of the hypocotyl, so that four traces are ultimately produced. These rapidly pass inwards and fuse with what plumular bundles may be present and form a broad U-shaped and compact mass of vascular tissue. This undergoes a rearrangement resulting in a triangular-shaped vascular cylinder, as viewed in transverse section, with the protoxylems situated at the corners and surrounded by phloem which speedily separates into three masses so that a triarch rootstructure results.

As regards the part played by the cotyledonary traces in the formation of the root-structure, the bundles of one seed-leaf formed one pole of the root, while the traces of the second cotyledon produced the remaining two poles.

The chief features of difference between the transition-phenomena of this plant and the other examples of $M$. spiralis are that in the former the number of cotyledonary bundles are more numerous, and the resulting root-structure is triarch instead of diarch.

In all cases the actual transition within the axis takes place with extreme rapidity, hence the hypocotyl for the major part of its length shows a root-like structure. 
Brief mention may also be made of an abnormality occurring in this aberrant example of $M$. spiralis. In the cortex of the hypocotyl, at about the level of the transition region, there obtained a short spindleshaped vascular strand which, throughout its course, was entirely isolated and unconnected with the rest of the vascular tissue. It consisted of a central core of short tracheides, about sixteen in number at the broadest part, and surrounded by a zone of cambium and cambiform cells. Sievetubes were absent, and what few immature xylem elements were present were developed centrifugally from the centre of the bundle. This probably represents an early commencement of the anomalous cortical strands which are a characteristic feature of the root of certain other Cycads, Cycas revoluta for example. Worsdell ${ }^{1}$ comments on the absence of cortical strands on vascular tissue in the stem of $M$. spiralis, although they are present in M. Fraseri.

\section{STANGERIA.}

\section{Stangeria sp.}

The seedlings of $S$.paradoxa have been investigated by Worsdell ${ }^{2}$ and Matte ${ }^{3}$ both of whom illustrate and describe the external appearance and enter into a detailed description of their anatomy: more especially the latter author, who gives some information regarding the transition-region which Worsdell did not deal with.

The seedlings are illustrated in Figs. 5-7, Pl. XXX. Fig. 5 represents quite a young seedling in which the plumule is breaking through the cotyledons; Fig. 6 illustrates an older seedling in which the plumule is more conspicuous and the primary root dichotomously branched; and Fig. 7 is that of a still older example in which the seed had dropped off and the cotyledons decayed. Of these the seedling represented in Fig. 6 is of some interest ; Prof. Pearson informs us that this bifurcation of the tap-root is not of unusual occurrence, and both Worsdell and Matte have recorded that dichotomous branching of the lateral roots obtain in Macrozamia spiralis and Ceratozamia mexicana, respectively.

The morphology and structure of the cotyledons does not differ in any important feature from that of Macrozamia; the cotyledons, however, do not appear to fuse so completely by their ventral faces, judging from the material at our disposal ; secretory cells are much less abundant and mucilage ducts apparently are absent; finally, although the bundles have more centripetal wood than centrifugal, the relative amount of the former is perhaps not so much, in all cases, as in Macrozamia.

As regards the number of vascular bundles in each seed-leaf there is much variation. Worsdell ${ }^{4}$ states that 'each cotyledon has, in its upper

1 loc. cit.

2 loc. cit.

3 Matte: Sur le développement morphologique et anatomique des germinations des Cycadacées.

4 loc. cit. 
part, four bundles arranged in a row parallel to the greatest width. . . . In the lower part of the lamina of the cotyledon and in its stalk, besides the row of four or five bundles, there are two or three others towards the ventral side, which may be orientated like those of the normal row or may lie sideways.' These inner bundles, on tracing them upwards, lose their phloems, and their xylems become united each with one of the normal strands. Towards the basal region the majority of the strands become concentric, a fact which Worsdell regards as of considerable phylogenetic importance.

Matte ${ }^{1}$ found four or five normal bundles in each seed-leaf in addition to a few strands towards the ventral surface. As regards these last, Matte does not find any phloem, 'ils se montrent simplement constitués par des vaisseaux isodiamétriques très larges, en groupes plus ou moins compacts qui réunis vers le haut aux faisceaux voisins de l'arc normal ...' Further, he disagrees with Worsdell regarding their significance. The strands here referred to are wanting in our material; they, therefore, are probably nothing more than individualistic variations of no theoretical import in the present connexion.

Passing on to our own observations, it was found that in one case the larger seed-leaf had five strands which, by the time the cotyledonary node had been reached, were reduced to three by the fusion of adjacent traces, while the smaller cotyledon had two throughout; in another example the smaller seed-leaf had two vascular bundles and the larger three towards the apex, but another was differentiated at a lower level which, at the cotyledonary node, fussd on to its nearest neighbour. The following description of the transition-phenomena is based upon the latter seedling, owing to the fact that the former one was so young that the vascular bundles of the hypocotyl were insufficiently differentiated.

\section{Transition.}

Matte ${ }^{1}$ has described some phases of the vascular rearrangements in the transition region. Our results are in accordance with his so far as the treatment coincides. At the cotyledonary node five traces enter the axis (Diagram 3, Fig. I), two from one seed-leaf and three from the other. These gradually pass to the central region of the axis, much more slowly than in Macrozamia, where the plumular bundles form conspicuous objects (Diagram 3, Fig. 2). Terming the seed-leaf-traces $a, b, c, d$, and $e$, and the plumular traces $p . I, p .2 \ldots$; the strand $d$ passes between $p . I$ and $p .2$ and fuses with them, and, at a slightly lower level, the trace $a$ effects a junction with p. 4 (Diagram 3, Fig. 3). The trace $e$ entirely fuses with $d$ (Diagram 3, Fig. 4), there is then a general union of the remaining bundles, which leads to the formation of a horseshoe-shaped vascular cylinder as viewed in transverse section (Diagram 3, Fig. 5). During these changes the 
wood has been becoming gradually less, especially the metaxylem, so that, in transverse section, it is impossible to distinguish with certainty the protoxylem from the metaxylem elements.

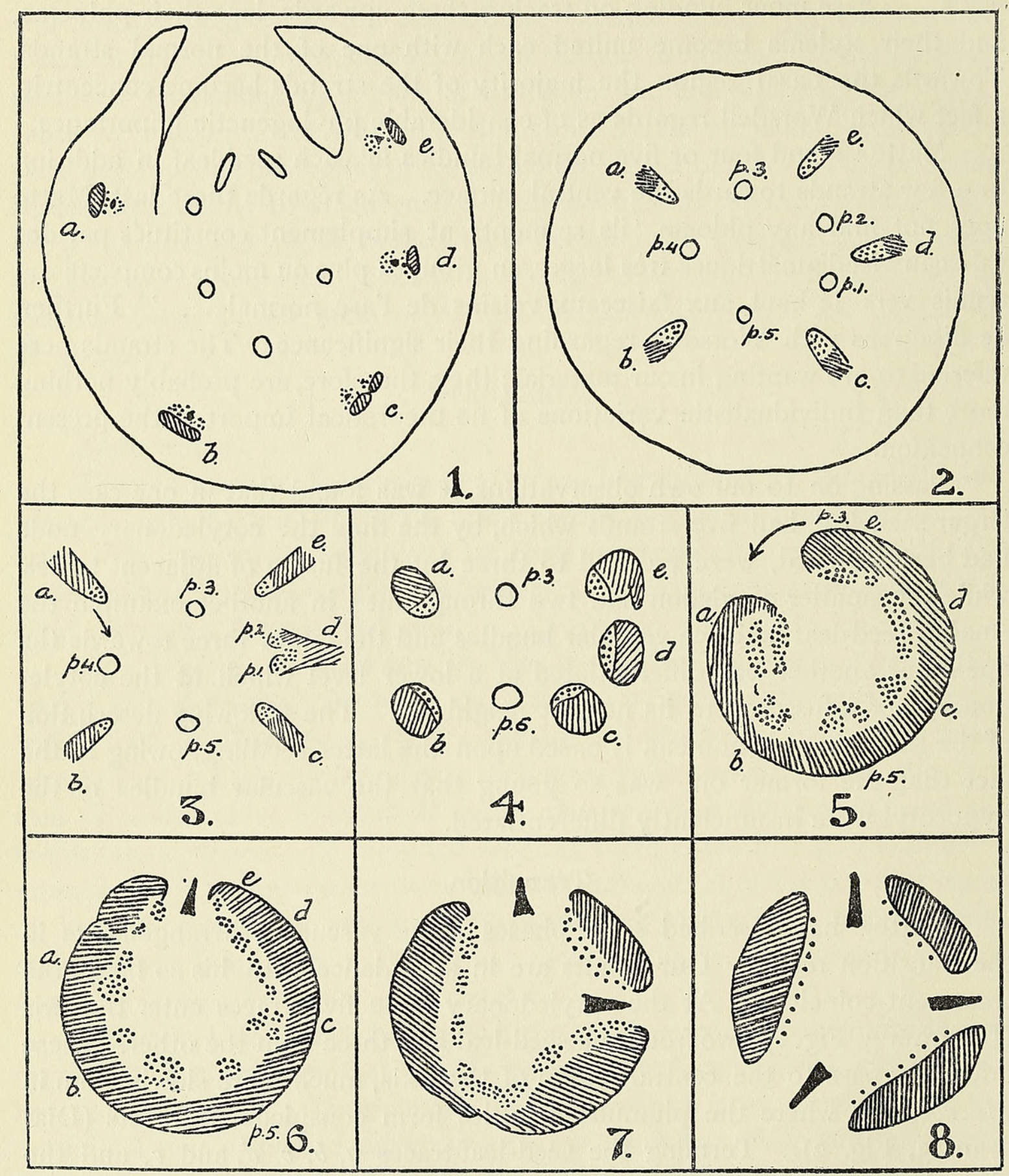

DiAgram 3. Stangeria sp.

That part of the cylinder marked $p .3$ now becomes detached and joins on to the opposite horn; in the gap thus produced a group of xylem elements is left in situ, and forms one pole of the root-structure (Diagram 3, Fig. 6). At a slightly lower level the phloem in the region between $c$ and $d$ divides, exposing another small mass of wood which forms another pole of the 
root-structure (Diagram 3, Fig. 7). A precisely similar vascular rearrangement takes place in the region of $b$ leading to the formation of the third pole of the triarch root-structure (Diagram 3, Fig. 8). In no case has a definite rotation of the protoxylem been made out; this tissue occupies its final position chiefly by the dying out of the metaxylem elements which would otherwise be in the way.

From the above facts it is seen that the vascular tissue from the smaller cotyledon forms one pole of the triarch root, while the other two poles are formed from the bundles of the larger seed-leaf. In this process the relative contributions of the different strands varied; and although in the later stages of the transition, owing to the compactness of the cylinder, it is almost, and sometimes quite, impossible to accurately delimit one strand from another, the positions of the xylem poles of the root, when compared with the relative positions of the seed-leaf traces, point to the fact that, in the seedling described, the bundles $b, c$, and $e$ are more important than $a$ and $d$.

As in Macrozamia an endodermis does not appear until a much lower level has been reached.

Worsdell found that the upper part of the primary root was triarch which appeared to be reduced to a diarch structure towards the apex; this was not so in the example described above, the dissimilarity is probably due to the difference in age between the seedlings investigated. Matte found that in one example the root was diarch at its base which, by the organization' of another pole, became triarch nearer the apex; while in an older seedling he found that 'la structure-racine, avec apparition de deux pôles trachéens, s'établit un peu plus bas, en même temps que, toujours sous l'influence des recloisonnements tubérisants, les lames radiales libéroligneuses secondaires s'espacent notablement les unes des autres avec contournements fréquents de leurs éléments constituants.

- Vers le bas cet espacement s'accentue régulièrement et aboutit finalement, à des niveaux très espacés, à la formation de trois, puis de quatre masses à peu près égales, avec différentiation progressive d'un troisième, puis d'un quatrième pointement trachéen suivant le mode indiqué précédemment.

'A un centimètre de la pointe, la structure primaire subsiste seule et, contrairement à ce qui se passe dans la germination $a$ [the younger seedling referred to above], les quatre pôles sont réunis entre eux par un bois primaire compact occupant tout l'axe de la racine.' ${ }^{1}$

In a footnote he makes the following observation: 'On remarquera que le nombre des pôles radicaux, de plus en plus grand à mesure qu'on se dirige vers l'extrémité de la racine chez le St.paradoxa, devient au contraire de plus en plus petit, dans ce même sens, chez. Ceratozamia mexicana'.

These are significant statements, more especially in view of the like 
observations and theoretical conclusions of Shaw ${ }^{1}$ on Araucaria Bidwillii, and the similar facts recorded by others besides ourselves both for Gymnosperms and Angiosperms. It is, however, not desired to discuss them here ; their theoretical importance will be considered in our general conclusions.

\section{DIOON.}

\section{Dioon edule, Lindl.}

The seedling has been described and figured by Matte ${ }^{2}$ and Thiessen, ${ }^{3}$ with whose observations we are in agreement. It resembles the seedlings of other Cycads, e.g. Macrozamia, very closely both as regards its general appearance, and also in its internal structure, with the minor exception that in Dioon the mucilage canals and secretory cells are more numerous.

The seed-leaves are closely apposed one to the other, but the line of demarcation is always obvious. At their apices the cotyledons are very irregular in outline, and there is no definite arrangement in the disposition of the vascular bundles (Diagram 4, Fig. I); at a lower level the strands take up a normal position, when it is seen that the larger seed-leaf has more bundles than the smaller. Following the traces downwards they are seen to become reduced in number which is brought about by the fusion of the extreme laterals. Thus, in one case, at the apex of the seed-leaves there were seven and six bundles respectively, but, at the base, the numbers were five and four (Diagram 4, Fig. 3) ; in another instance each cotyledon had four strands at the cotyledonary node.

These observations are of the same nature as those of the two authors cited above. Thus Thiessen remarks that the tip of each cotyledon has one concentric strand which abuts immediately against the epidermis. At lower levels this bundle divides into eight, which fuse in pairs so that four strands result. In two seedlings it was found that one of the cotyledons had five bundles at its base.

In the two seedlings described by Matte, one had four traces in each cotyledon, while the other example had four in one seed-leaf and two in the other together with two much smaller ones which, in the hypocotyl, fused on to the nearest plumular traces and played no part in the transition; the resulting root-structure was triarch, while in the former case it was tetrarch.

Both authors enter fully into histological details, which it is not proposed to consider here.

\section{Transition.}

Matte and Thiessen also describe and illustrate, more or less briefly, the transition-phenomena. The latter writer remarks that 'the four strands

1 Shaw: The Seedling Structure of Araucaria Bidwillii (Ann. Bot., xxiii, 1909).

${ }^{2}$ Matte: Recherches sur l'appareil libéro-ligneux des Cycadacées (Caen, I904).

3 Thiessen : The Vascular Anatomy of the Seedling of Dioon edule (Bot. Gaz., xlvi, 1908). 
of each of the petioles of the cotyledons may be said to join two by two. Just before reaching the central cylinder the inner strands of each fuse, and the outer strands of the one fuse with the outer strands of the other, the four strands thus formed giving rise to the four protoxylem groups'.

Series $A$. The top of the hypocotyledonary axis is occupied by nine cotyledonary traces, five derived from one seed-leaf and four from the other (Diagram 4, Fig. 3, $a \ldots$. i). These pass with some degree of rapidity towards the centre, and the three traces $b, c$, and $d$, derived from the larger cotyledon, fuse to form one structure; at the same level $e$ and $f$, of the smaller seed-leaf, have approached one another pretty closely (Diagram 4, Fig. 5). At a lower level $e$ and $f$ effect a junction as they enter to form part of the central cylinder, and so also do the bundles $g$ and $h$ (Diagram 4 , Fig. 6). The strand $a$ enters the cylinder by itself and so also, at a lower level, does $i$. The vascular cylinder is now concentric, and the bundles have lost their identity, that is to say it is impossible to delimit their boundaries with absolute certainty.

The organization of the root-structure proceeds rapidly, two xylem poles, in the plane of the cotyledons, are differentiated quickly; then two other poles in the intercotyledonary plane are formed. The phloem is still intact; but, as soon as these last xylem rays are produced, the bast divides first opposite the xylem rays first differentiated, and then, at a lower level, opposite the intercotyledonary poles.

With regard to the relative value of the cotyledonary strands in the formátion of the root-structure, $g$ and $h$ together form one pole; $e$ and $f$ another pole; $i$, by itself, the third; and $b$ and $c$, the fourth pole. The strands $c$ and $d$ appear to be of no particular value. A comparison of Diagrams 2 and 4 shows that the transition of this example of Dioon edule and Macrozamia is in many respects identical.

Series $B$. This seedling differed from the first in the fact that the hypocotyl, at its upper end, had eight vascular strands, an equal number being derived from each seed-leaf. The behaviour of each of these was very regular: the bundles of each cotyledon consist of a central pair which is bounded on either side by one strand. Each central pair of traces organize that pole of the root-structure situated in the plane of the cotyledons; and each of the lateral bundles gives origin to one pole so that a hexarch rootstructure results. There is thus a considerable difference between these two seedlings of Dioon edule. On the other hand there are important points of similarity between them. In each case those two poles of the root-structure situated in the plane of the seed-leaves was organized first and were the strongest ; those poles in the intercotyledonary plane were differentiated at a lower level; further, the division of the phloem-ring first took place opposite the two protoxylem rays first organized.

In no case has a rotation of the protoxylem been seen, the remarks on 


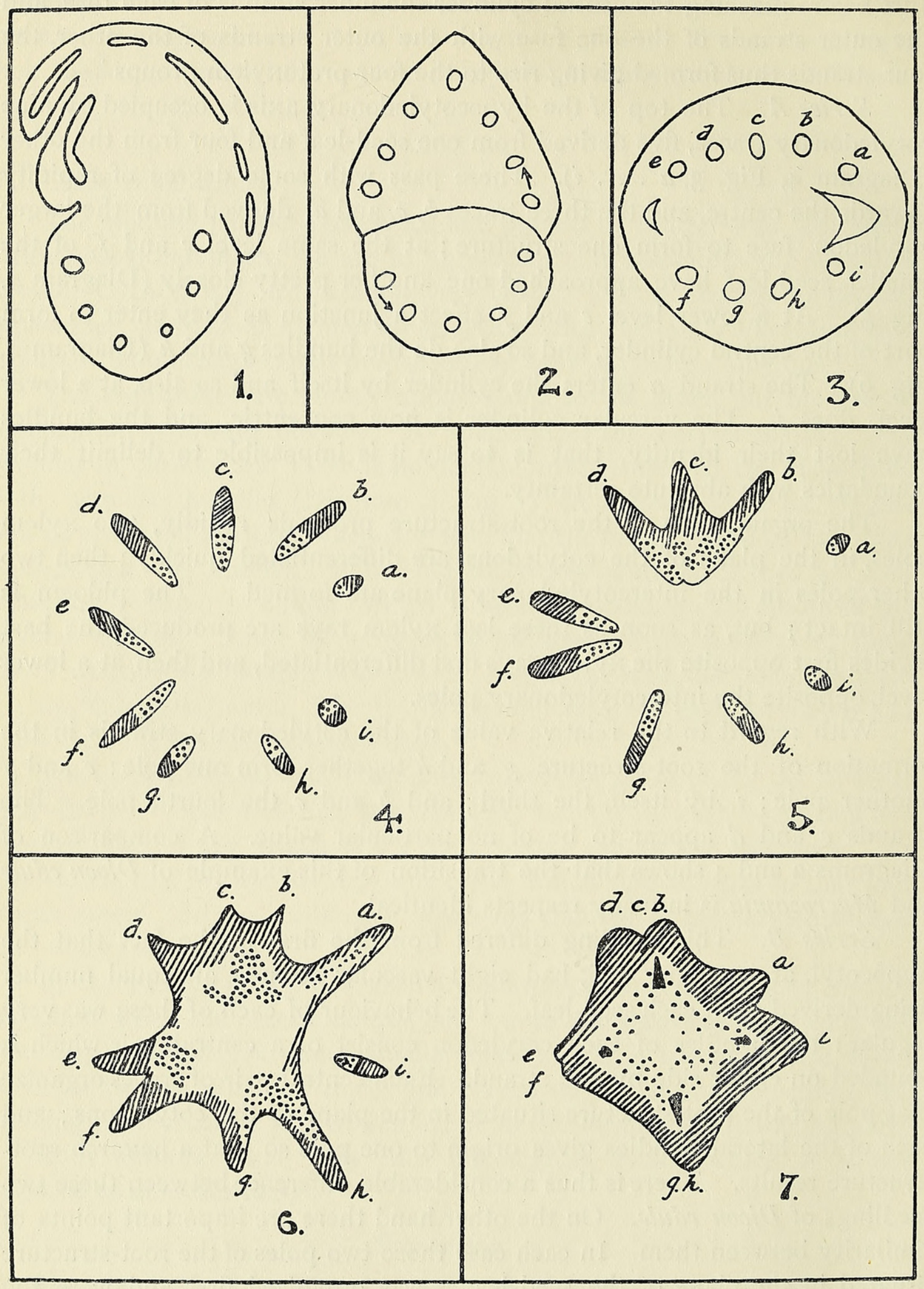

Diagram 4. Dioon edule. 
this feature made at the end of the description of Macrozamia apply equally well here.

A comparison of the above account with that given by Matte and Thiessen shows that there is much variation; our second seedling (Series B) most closely conforms with what Thiessen found, but instead of the four lateral cotyledonary bundles forming two poles of the root they produced four, so that the resulting structure was hexarch instead of tetrarch. In the first seedling described above the two poles in the cotyledonary plane were formed from the three central bundles of one seed-leaf, and from the two corresponding strands of the other; and the intercotyledonary poles were formed, one from the extreme lateral seed-leaf-traces on the one side, and from a single lateral bundle on the other. Further, the intercotyledonary protoxylem rays of the root-structure were in each example organized at a level lower than those in the cotyledonary plane.

\section{ENCEPHALARTOS.}

Encephalartos Altensteinii, Lehm.

The seeds of this plant are larger than those of Dioon, Stangeria, and Macrozamia, and the seedling is much stouter, especially older ones which have a thick hypocotyl resembling, in many features, those of some hypogeal species of Araucaria. Different stages are represented in Pl. XXX ; Fig. 8 shows the cotyledons embedded in the prothallus to be of unequal size, and it will be noticed that the tip of the longer one is wrapped around the apex of the shorter ; Fig. 9 indicates the external appearance of a seedling a little older than the previous one; and, lastly, Fig. Io represents a still older seedling with a thickened hypocotyl. Periderm formation begins early, and is indicated in these drawings by the reticulate markings.

The cotyledons, both as regards their morphology and anatomy, do not differ in any feature of importance from those of the plants previously considered; a cotyledonary tube is formed.

\section{Transition.}

Each cotyledon has five vascular bundles, a central strand bounded on each side by a pair of laterals, all of which are much the same in size, although, in some examples, the extreme lateral traces may be a little smaller than the rest. These bundles travel towards the centre of the hypocotyl very gradually, much more slowly than in Dioon and Stangevia, and, during this passage, the individual strands of each pair of laterals join together so that, when the central region of the axis is reached, there are six cotyledonary traces, three derived from each seed-leaf, alternating with the bundles from the plumule. Their arrangement is quite regular, the central cotyledonary bundles being in the plane of the cotyledons and bounded on each side by a lateral. 
A complicated series of anastomoses takes place between the cotyledonary and plumular traces, which results in the formation of a closed vascular ring, enclosing a mass of parenchyma, of the same nature as has been described above for Dioon. The protoxylem rays are now organized, but not all at the same level. First, a ray is formed from the central bundle of one of the seed-leaves, and situated in the plane of the cotyledons; then, at successively lower levels, of course not far distant one from the other, two other protoxylem rays are formed, each from the two lateral strands of the other seed-leaf, and inclined at an angle to the cotyledonary plane. The phloem-ring divides opposite each protoxylem group, and thus there is formed a triarch root-structure.

This triarch arrangement persists for some little distance downwards towards the root-apex, but, at a lower level, a new protoxylem group comes into being and the band of phloem opposite it divides, thus a tetrarch structure results; at a still lower level a similar occurrence takes place in a corresponding position on the other side of the central cylinder, so that a pentarch arrangement obtains. This increase in the number of poles in the root-structure appears to be a general feature of this plant, for in two other cases the initial triarch arrangement became tetrarch at lower levels, a character shared by Stangeria, Ceratozamia mexicana, and other plants. ${ }^{1}$ We have found no instance of the pentarch or tetrarch structure giving place to a triarch arrangement such as Matte described for Stangeria, Ceratozamia, and Encephalartos Barteri; this is probably due either to the fact that the seedlings examined by us were either too young or, when sufficiently old, to the decay of the greater length of the root. It may be remarked here that the above account does not agree in certain respects with that given by Tansley and Miss Thomas. ${ }^{2}$ They describe each cotyledon as having six vascular bundles which organize a tetrarch root-structure. In the examples examined by us the seed-leaves each had five bundles at the node, with one exception, when four were present and a triarch root-structure invariably was formed first.

Matte ${ }^{3}$ gives a relatively brief description of Encephalartos Barteri. The specimen examined by him had three cotyledons, of which one was larger than the others, this larger one had two vascular bundles in its tip, whereas the smaller seed-leaves had but one each. At a lower level more strands arose, so that at the base each cotyledon had four. These traces remained separate one from the other until they had entered the hypocotyledonary axis, when those of each seed-leaf fused together to form a single concentric strand; the three bundles thus produced fused with the plumular vascular tissue at different levels, and ultimately produced a pentarch rootstructure, which, at a lower level, became reduced to triarch.

${ }^{1}$ Matte, Shaw, loc. cit.

${ }^{2}$ British Association, Section K, York, I906.

${ }^{3}$ loc. cit., I904. 
The behaviour of the cotyledonary traces of this species is obviously different to that of the same structures of $E$. Altensteinii, and we have seen nothing exactly like it in other genera. It is interesting to find that Karsten ${ }^{1}$ has described each cotyledon of Zamia muricata as receiving one vascular trace from the axis which branches in the higher regions of the seed-leaves. This apparently does not obtain in all species of Zamia, for Miss Dorety, in her paper on Ceratozamia, ${ }^{2}$ states that some species of Zamia are of the same type, as regards their structure, as Dioon edule. To return to $E$. Barteri, the later vascular rearrangements leading to the formation of the root-structures apparently are similar to those of Macrozamia spiralis.

The following descriptions deal with plants which we have not had the opportunity of examining. In many cases the authors cited have followed in their descriptions of the transition-phenomena a method different to that pursued by us; in such instances we have described the facts in our own way for the sake of uniformity.

\section{CYCAS.}

Cycas siamensis, Miq. According to Matte ${ }^{3}$ the transition-phenomena are similar to those described by him for Dioon edule with this difference, that the lateral cotyledonary bundles do not form any intercotyledonary poles, so that the resulting root-structure is diarch. As regards Cycas in general the following paragraph is quoted from Miss Thomas ${ }^{4}$ as it embodies a summary of some of the facts observed by her and Tansley. ${ }^{5}$

'It appears that Cycad cotyledons are almost without exception destitute of a midrib, and have four or six bundles at their base; that the transition features take place so near the cotyledonary node that the hypocotyl is root-like in structure; and that the primary root is in most cases tetrarch, with a strong tendency to reduce near its apex to diarch. The genus Cycas would appear to be most aberrant, for while $C$. revoluta forms a tetrarch root, $C$. siamensis ... forms a link between $C$. revoluta and C. Rumphii, which is diarch through the absence of intercotyledonary poles. Further, $C$. revoluta may have its two central bundles replaced by a single one, which, however, plays the part of two.'

There is apparently some variation, for Bower ${ }^{6}$ states that in Cycas Seemanni there may be in the cotyledon a median bundle, or two equal ones disposed symmetrically near the centre of the cross section, and between these extremes intermediate modes of arrangement may occur. $\mathrm{He}$

\footnotetext{
${ }^{1}$ Karsten : Organographische Betrachtungen der Zamia muricata (Abh. d. Berlin. Akad., I93. $\left.185^{6}\right)$.

${ }^{3}$ loc. cit.

${ }^{4}$ loc. cit.

2 Bot. Gaz., xlvi, I908.

${ }^{6}$ Bower: On the Comparative Morphology of the Leaf in the Vascular Cryptogams and Gymnosperms (Phil. Trans. Roy. Soc., Lond., I75. I884).
} 
goes on to remark that 'it might be assumed that the median bundle, when present, is merely the result of the coalescence of two equal bundles, which might be found to be distinct in the upper part of the cotyledon; but this is not the case, since the median bundle has been found to maintain its individuality in an upward direction'.

Further, Miss Thomas and Tansley found that Cycas revoluta had a tetrarch root, whereas Van Tieghem ${ }^{1}$ describes it as being diarch, and Worsdell ${ }^{2}$ as triarch or tetrarch.

Finally, as regards the number of bundles in the cotyledons, Worsdell describes those of Cycas revoluta as having five strands in the apical parts, which at lower levels fuse together so that three enter the axis.

\section{Ceratozamia.}

Ceratozamia mexicana, Brongn. is of particular interest, owing to the presence of one seed-leaf only, the other being frequently aborted. Our knowledge of the seedling structure of this plant is practically complete, and is due to the researches of Miss Dorety ${ }^{3}$ and Matte. ${ }^{4}$ Considering the work of the former author first, the cotyledon, which in many cases is lobed at the tip, has many bundles in its distal region which increase in number towards the base and then undergo a reduction in number so that, finally, three strands only enter the axis. Reading the serial sections in the opposite direction three traces enter the seed-leaf from the hypocotyl, and each dichotomizes several times, hence, in the upper parts, the number of bundles may be fifteen, which undergo reduction as the apex is reached. The three traces each behave in the same manner, "the median one being no more a "double " bundle than any of the others.' The transition takes place rapidly, each cotyledonary strand giving rise to one pole of the rootstructure, which is either triarch or tetrarch; whether the vascular arrangement of the root be triarch or tetrarch seemingly depends upon the degree of development attained by the median bundle of the aborted cotyledon.

When the second seed-leaf is made to develop, the transition-phenomena closely resemble those described for Dioon edule by Matte ${ }^{5}$ and Thiessen ${ }^{6}$; three strands enter the axis from each seed-leaf, one central and two lateral, the two central ones organize those two poles of the tetrarch root-structure situated in the cotyledonary plane, and the corresponding, i. e. opposite, lateral strands of the seed-leaves fuse together and form the two poles in the intercotyledonary plane.

Turning to the results obtained by Matte, who enters very fully into the anatomy and morphology of seedlings of different ages, it is clear that

1 loc. cit.

${ }^{2}$ loc. cit.

3 Dorety: The Embryo of Ceratozamia, a physiological study (Bot. Gaz., xlv, I908). The Seedling of Ceratozamia (Bot. Gaz., xlvi, I908).

4 loc. cit., 1908.

5 loc. cit., I904.

${ }^{6}$ loc. cit. 
the same kind of variations obtain in this plant as we have shown to occur in others. As regards morphology, the material at his disposal contained one seedling with two cotyledons naturally developed, of these one was slightly larger than the other, and each had in the upper regions ten or twelve vascular bundles, which by fusion became reduced to three in the basal parts. There is no cotyledonary tube such as obtains in Encephalartos Altensteinii. The cotyledonary strands enter the axis and fuse on to the plumular traces, thus forming an elliptical concentric vascular cylinder from which a diarch root-structure is organized, the two poles being in the plane of the cotyledons. At a lower level a third pole is differentiated. In another example having but one cotyledon eight vascular strands entered the axis, fused in pairs, and gave rise to a triarch root-structure.

Ceratozamia longifolia $+\times C$. mexicana $o^{7}$. The seedlings of this hybrid have been described by Van Tieghem, ${ }^{1}$ who does not enter at all fully into the transition-phenomena. Monocotyledony appears to be the rule, but one out of four examples examined seemingly had two cotyledons of very unequal size; Van Tieghem concludes that this specimen was really monocotyledonous, and the apparent smaller second seed-leaf was nothing more than a lobe of the larger one. The cotyledons generally have eight vascular strands which fuse in pairs as they are traced downwards, so that four traces enter the axis and give rise either to a triarch or a tetrarch root. The apparent dicotyledonous specimen had six seed-leaf bundles and the root-ștructure was triarch.

\section{MICROCYCAS.}

Microcycas calocoma. The germination and structure of this plant has been described by Miss Dorety. ${ }^{2}$ The cotyledons are two in number, and for the greater part of their length are fused very closely together by their ventral surfaces; basally they form a tube. Each seed-leaf has in its upper region eight to ten vascular bundles, all of which are derived from the branching of three. The transition is of the same type as that occurring in Dioon edule, as described by Matte and Thiessen. The corresponding lateral bundles of each cotyledon fuse together, thus four strands obtain. ' The metaxylem and phloem divide, as usual, and the resulting portions swing to right and left, the right half of the phloem of each joining with the left half of that of the next, with sometimes the lowermost extremities of leaf-trace phloem intervening. There is thus produced the characteristic root-structure, four groups of phloem alternating with four double-fan-shaped xylem groups.' In some cases the tetrarch arrangement became reduced to triarch towards the apex.

1 Van Tieghem: Symétrie de la structure des plantes (Ann. Sci. Nat., Bot., xiii, I873).

2 Dorety: Vascular Anatomy of the Seedling of Microcycas calocoma (Bot. Gaz., xlvii, I 909). 


\section{BOWENIA.}

Bowenia spectabilis. Our knowledge of the seedling structure of this plant is due to the work of Pearson, ${ }^{1}$ who gives an extended description of the morphology and structure of the plant in question. Each cotyledon contains from four to seven vascular bundles, the neighbouring ones of which may fuse together so that four strands enter the hypocotyledonary axis from each seed-leaf. These, in the axis, join together, and with the traces derived from the plumule form a concentric pithless vascular cylinder, the centre of which is occupied by protoxylem elements. From this central strand there is quickly organized a diarch root-structure which becomes triarch at a slightly lower level, which arrangement in turn gives place to a pentarch root-structure which persists for some distance downwards. Whether, in older seedlings, this pentarch organization becomes reduced to a diarch structure, such as Matte found to obtain in Stangeria and Ceratozamia, Pearson does not state.

From Pearson's account it appears that the transition-phenomena in Bowenia spectabilis are of the same type as generally obtain in Macrozamia spiralis.

\section{ZAMIA.}

As far as has been seen there exists no account of the seedlingstructure of species of this genus of any importance in the present connexion. Van Tieghem ${ }^{2}$ states that in Zamia furfuracea the number of cotyledons are usually two, but sometimes one and sometimes three obtain. In dicotyledonous examples each seed-leaf has four vascular bundles; in the monocotyledonous specimen there were eight cotyledonary strands; and, finally, in the tricotyledonous plant, each seed-leaf had two vascular bundles. A cotyledonary tube commonly is formed, and the rootstructure is tetrarch.

Zamia spiralis sometimes has the tips of the cotyledons lobed to such a degree as to suggest a pinnate lamina ${ }^{3}$; a fact which has also been observed by Miss Dorety, ${ }^{4}$ who states that species of $Z$ amia have seedleaves with four to ten lobes, and that the transition is of the same type as in Dioon edule.

\section{SUMMARY.}

\section{Cotyledons.}

I. In all the plants examined the seed-leaves are hypogeal, and are embedded in the prothallus throughout their existence.

2. They are very generally two in number; three have been observed in Ginkgo biloba.

1 Pearson: Anatomy of the Seedling of Bowenia spectabilis (Ann. Bot., xii, 1898).

${ }^{2}$ loc. cit. ${ }^{3}$ Sachs : Text Book, 2nd Ed., p. 50I (Oxford, I882). $\quad$ \& loc. cit., I909. 
3. The seed-leaves are frequently unequal in size, the larger one overlapping the tip of the shorter ; there is a marked tendency to the formation of lobes, especially at the apex; and a short basal cotyledonary tube is formed in some cases, e. g. Encephalartos Altensteinii.

4. In the Cycadaceae the cotyledons are more or less intimately fused by their ventral surfaces, especially in the upper parts which are embedded in the prothallus.

5. As regards structure, stomata generally are present; the mesophyll is homogeneous ; secretory cells and canals are common; and the vascular bundles are mesarch or exarch in varying degrees.

6. The number of bundles in each cotyledon varies (see table below); if the seed-leaves of a seedling are unequal in size, the smaller one generally has fewer bundles than the larger.

7. In all cases the bundles are more numerous in the central region than in the basal parts and the tips; or, in other words, the strands passing into the seed-leaves from the axis branch or dichotomize sometimes very regularly as in Ginkgo; the branches may subsequently fuse together in the apical regions.

\section{Transition-region.}

8. In all cases the transition-phenomena take place rapidly, so that the hypocotyl throughout the greater part of its length shows root-structure. These changes are most rapid in Macrozamia spiralis and slowest in Encephalartos Altensteinii. Dioon edule and Stangeria sp. occupy an intermediate position as regards the features in question.

9. In all the plants examined the vascular rearrangements take place within the hypocotyl.

I0. In no Cycad has a rotation of the protoxylem of the seed-leaftraces been observed; the amount of centrifugal wood is so small that only a slight rearrangement is required in order to bring the protoxylem into the exarch position. In Ginkgo such a rotation does take place within the hypocotyledonary axis.

I I. In Ginkgo each cotyledonary bundle, in dicotyledonous examples, gives rise to two poles of the root-structure; in the tricotyledonous specimen examined each seed-leaf-strand gave origin to one pole, so that the resulting root-structure was triarch.

12. In the Cycads examined-Macrozamia spiralis, Stangeria sp., Dioon edule, and Encephalartos Altensteinii-the cotyledonary bundles fuse with the plumular traces, and ultimately form a central cylinder which consists in Macrozamia spiralis either of a central rod of xylem surrounded by phloem, or of an open U-shaped strand which soon closes to form a triangular-shaped vascular cylinder, as viewed in transverse section, enclosing a central mass of parenchyma; in Stangeria, 
of a horseshoe-shaped central cylinder enclosing a central mass of parenchyma; in Dioon edule and Encephalartos Altensteinii of a concentric cylinder with a central pith.

13. The fusion of the cotyledonary traces with one another, or with the plumular bundles, or with the central cylinder, does not always take place at the same level.

I4. The seed-leaf bundles are not of equal value in the production of the root-structure; some traces play a wholly subordinate part, and the behaviour of similarly situated bundles in different individuals of the same species varies. Thus in Dioon edule, in one example, the two poles of the root-structure situated in the plane of the seed-leaves were organized from the three central bundles of one cotyledon, and the two central strands of the other seed-leaf; and the intercotyledonary poles were formed, one from the extreme lateral traces on the one side, and from a single lateral bundle on the other. In another example the four lateral traces, two from each cotyledon, each formed one pole of the root-structure, so that there were four intercotyledonary poles in addition to the two situated in the plane of the cotyledons.

In Stangeria it is more difficult to allocate values; one pole was formed chiefly from a lateral strand of one of the seed-leaves, the second pole from the other lateral bundle and part of the central trace of the same cotyledon, while the third pole was organized chiefly from the vascular tissue of one of the two bundles of the other cotyledon.

In Encephalartos Altensteinii, the central bundle of one cotyledon organizes one pole of the root-structure; the other two poles are formed from the two lateral traces of the other seed-leaf.

I5. The poles of the root-structure are formed successively in Stangeria and in Encephalartos Altensteinii. In the case of Dioon edule the two poles situated in the plane of the cotyledons are the first to appear, those in the intercotyledonary plane being organized at a slightly lower level.

I6. In one seedling of Macrozamia spiralis an isolated concentric strand of vascular tissue occurs in upper regions of the hypocotyl.

\section{Root.}

I7. In Ginkgo an addition of protoxylem elements may occur after the root-structure has been attained.

18. In Stangeria sp. the primary root may dichotomize.

I9. After the initial root-structure has been attained the number of poles may be increased at lower levels; thus, in Encephalartos Altensteinii, the initial structure may be triarch but it becomes tetrarch or pentarch at lower levels. 
20. The following table shows the variation in the number of bundles in the base of the cotyledons of the plants named, and also the relation between the number of poles in the root-structure and the cotyledonary strands.

This table is based on observations recorded in the literature on the subject, together with our own.

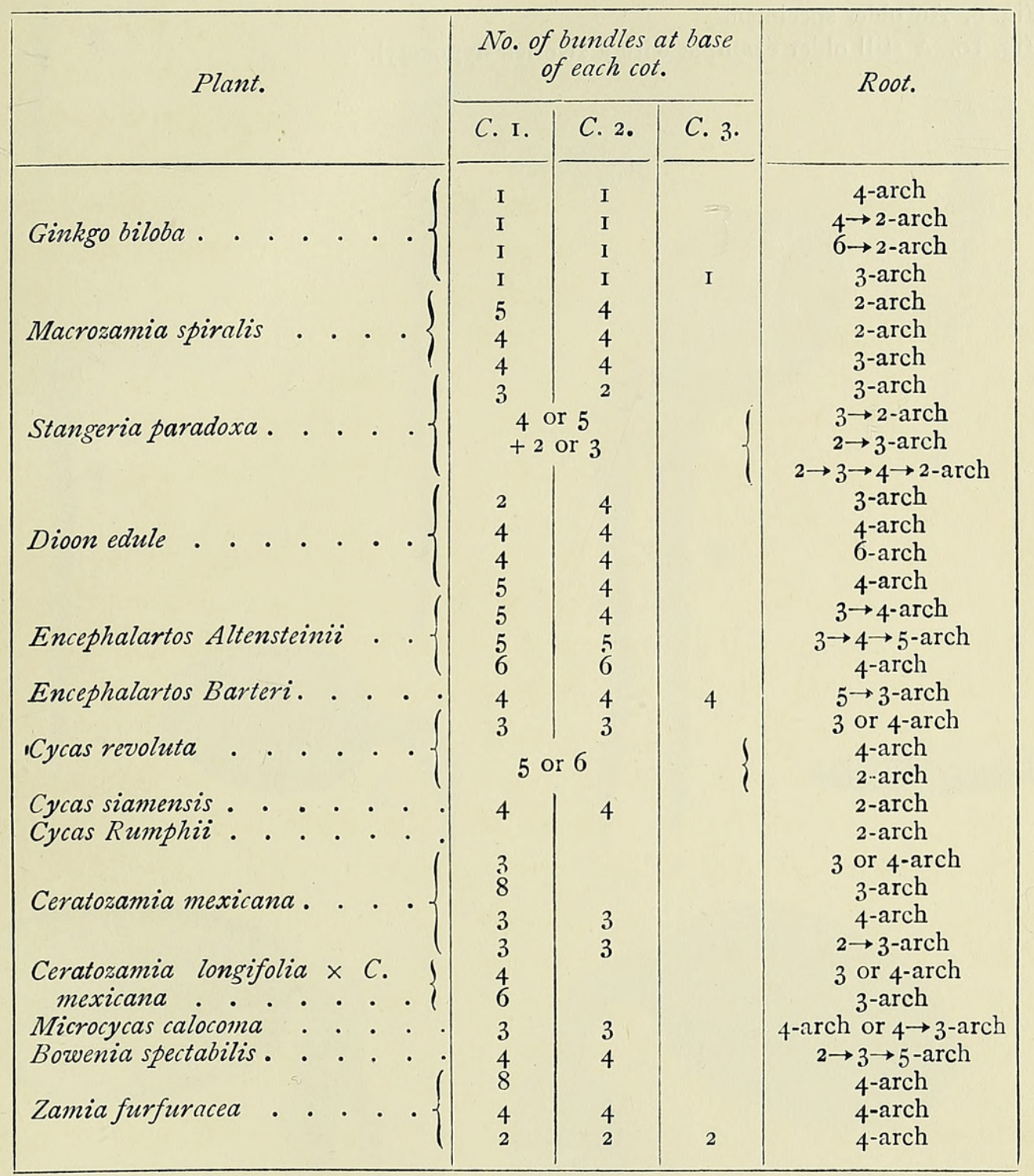

\section{EXPLANATION OF PLATE XXX.}

Illustrating Mr. T. G. Hill's and Miss de Fraine's paper on the Seedling Structure of Gymnosperms. III.

All the figures are natural size.

Fig. I. A seedling of Ginkgo biloba.

Fig. 2. An older example showing a greater development of the plumule.

Fig. 3. A tricotyledonous specimen of Ginkgo. 


\section{$45^{8}$ Hill and de Fraine.-Seedling Structure of Gymnosperms.}

Fig. 4. A young seedling of Macrozamia spiralis.

Fig. 5. A young seedling of Stangeria sp.; the plumule is just showing.

Fig. 6. An older example showing the cotyledons embedded in the endosperm, a greater development of the plumule, and a dichotomously-branched primary root.

Fig. 7. A still older seedling of Stangeria sp. in which the cotyledons have decayed and the hypocotyl enlarged.

Fig. 8. A seedling of Encephalartos Altensteinii showing the unequal cotyledons embedded in the prothallus.

Fig. 9. An older specimen.

Fig. Io. A still older example with a swollen hypocotyl. 
Annals of Botany,

Vol. XXIII, Plate XXX.
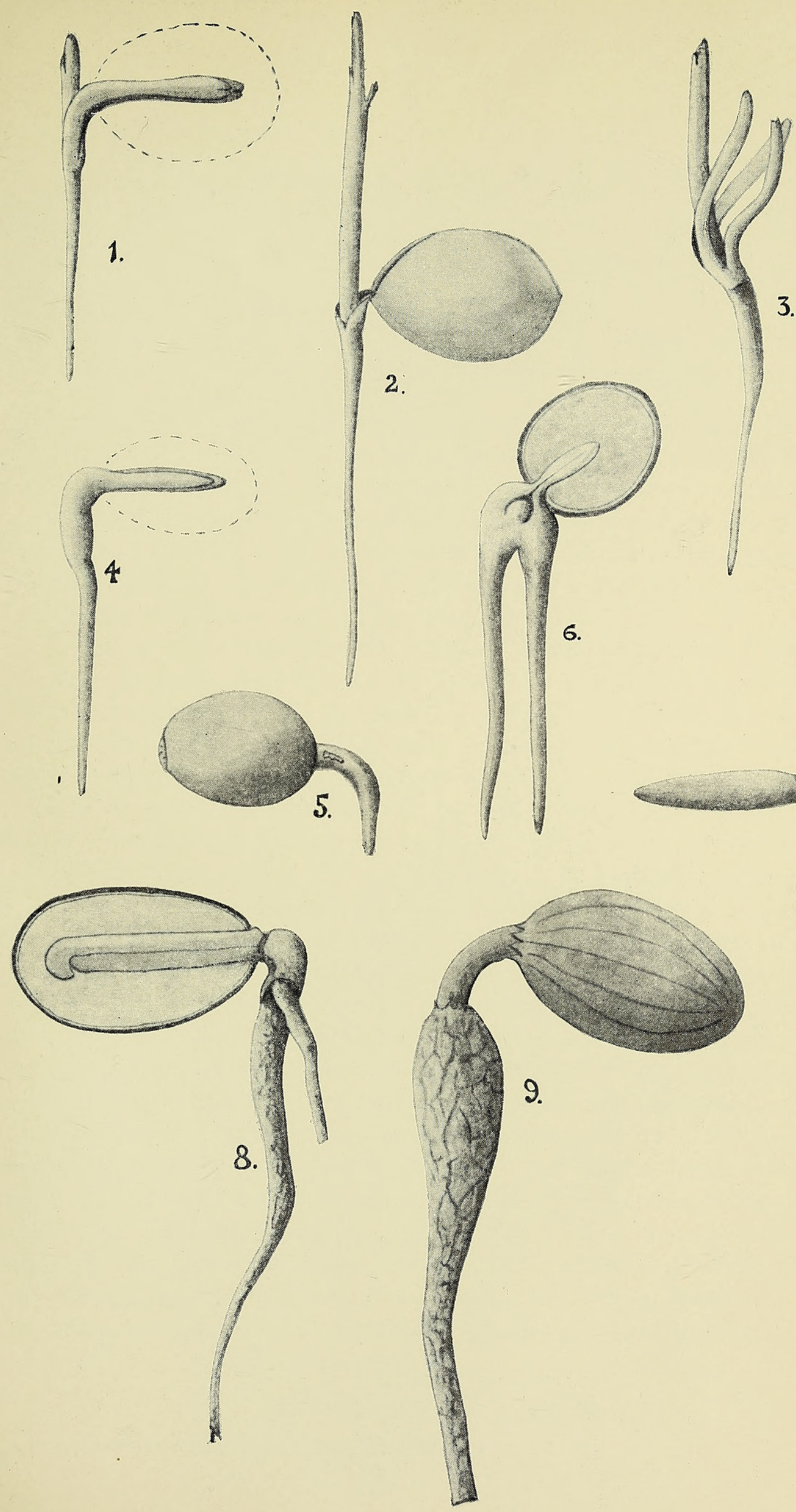

3.

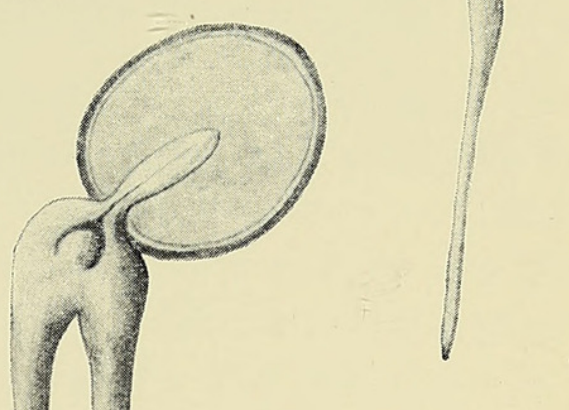

6.

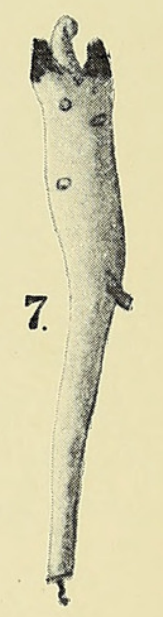

10.

T. G. H. del.

HILL \& DE FRAINE-SEEDLING STRUCTURE OF GYMNOSPERMS III. 


\section{$2 \mathrm{BHL}$ Biodiversity Heritage Library}

Hill, T. G. and De Fraine, E. 1909. "On the seedling structure of gymnosperms. III." Annals of botany 23, 433-458.

https://doi.org/10.1093/oxfordjournals.aob.a089230.

View This Item Online: https://www.biodiversitylibrary.org/item/236540

DOI: https://doi.org/10.1093/oxfordjournals.aob.a089230

Permalink: https://www.biodiversitylibrary.org/partpdf/318965

\section{Holding Institution}

Smithsonian Libraries

\section{Sponsored by}

Biodiversity Heritage Library

\section{Copyright \& Reuse}

Copyright Status: Not in copyright. The BHL knows of no copyright restrictions on this item.

This document was created from content at the Biodiversity Heritage Library, the world's largest open access digital library for biodiversity literature and archives. Visit BHL at https://www.biodiversitylibrary.org. 